\title{
Lexis
}

Journal in English Lexicology

$1 \mid 2008$

Polysemy

\section{La polysémie : contributions à l'étude et au traitement grammatical, lexicogénique et lexicographique du phénomène}

Introduction

\section{Catherine Paulin et Henri Béjoint}

\section{OpenEdition}

Journals

Édition électronique

URL : http://journals.openedition.org/lexis/747

DOI : $10.4000 /$ lexis. 747

ISSN : 1951-6215

Éditeur

Université Jean Moulin - Lyon 3

Référence électronique

Catherine Paulin et Henri Béjoint, « La polysémie : contributions à l'étude et au traitement

grammatical, lexicogénique et lexicographique du phénomène », Lexis [En ligne], 1 | 2008, mis en ligne le 04 juillet 2008, consulté le 23 septembre 2020. URL : http://journals.openedition.org/lexis/747

DOI : https://doi.org/10.4000/lexis.747

\section{c.) (i) (9)}

Lexis is licensed under a Creative Commons Attribution-NonCommercial-NoDerivatives 4.0 International License. 


\section{Introduction}

\section{Polysemy: contributions to the grammatical, lexicogenic and lexicographic study of the phenomenon}

Polysemy is one of the major problems encountered by semanticists, who sometimes prefer to refer to it as "ambiguity". All the same the question seems simple: everyone knows that a word may well have several senses. However such apparent simplicity is misleading. Lexicographers know how difficult it is to determine the number of senses of a word, to define them, to say where one ends and another begins. In actual fact, to be in a position to answer these questions requires prior agreement as to what is understood by "meaning" as opposed to "sense" - which is far from being the case.

Lexical semantics today is very much concerned with polysemy which is no longer considered as an anomaly but rather as an intrinsic and essential feature of all natural languages. In addition, the study of polysemy has acquired renewed importance in the field of automatic translation of natural languages: it is a key notion for automatic data understanding and language comprehension. Amongst the major authors of recent works, researchers in cognitive semantics, corpus linguistics and lexicographers all agree on certain points:

- ambiguity rarely occurs in discourse, for human beings, who are nearly always in a position, thanks to contextual elements, to disambiguate the comprehension of the informative content but it remains a source of problems for automatic comprehension;

- there is no simple means to identify the different senses of a word;

- the difference between homonymy on the one hand and polysemy on the other is to be thought of in terms of a continuum rather than a dichotomy.

Some corpus linguists and lexicographers end up questioning the existence of senses. Such a position jeopardizes any theoretical stand as well as further research in the field. Therefore the question of ambiguity still exists, even if it has been displaced.

Semanticists have devoted most of their work to substantives - nouns or noun equivalents - which is easily accounted for by their being inspired by language philosophers whose interest lies in the exploration of the ontological essence of "things" more than in lexical meaning. It is also related to the fact that reference - the referential value of words - cannot be dissociated from the study of substantives. For some decades however, research has been carried out on other parts of speech as well: verbs, adjectives, prepositions. The recurring lines of argument in the present volume all belong to a long-standing tradition of lexical and grammatical semantics, focused today on cognition.

Polysemy has grown into a vast field of investigation: the papers collected in this volume represent a modest contribution only. Puckica studies the polysemy of grammatical words within the framework of construction grammars (CG) in which the different senses of a word can be construed as different actualizations of an abstract semantic invariant core meaning, or, in the theory of the prototype, central or peripheral occurrences of a category. In her paper, Gilquin makes a study of the English verb take in which she draws a comparison between the lexical network developed by Norvig \& Lakoff (1987) with corpus data and elicitation data produced by native speakers both from a linguistic point of view (does the intuition-based model reflect corpus-based frequency?) and a cognitive point of view (does the intuition- 
based model reflect the saliency that emerges in the mind of the average speaker?). She concludes that the model does not stand the test of empirical evidence but can still have its relevance in a theory of polysemy. Using corpus data, Lorenzetti argues that the majority of the senses of the English verb see retain traits of their prototypical meaning which is used as the starting point for potential semantic enlargement. Stammers compares how six recent English dictionaries deal with the polysemy displayed by the adjectives unbalanced, idle, canonical and particular. Adjectives form a highly varied word-class and their polysemy is heavily context-dependent. He shows that lexicographers react to the challenge of their polysemy in different ways and even concludes that some adjectives that are considered to be polysemous in fact are not truly so. The author also observes that some adjectives have a clear hierarchy of senses whereas others form a semantic cline which resists analysis. Dury's approach is innovative: her analysis is based on the role of polysemy in the diachronic formation of a specialized lexicon in the field of petroleum. The study of a corpus of texts published between 1800 and 1950 shows that the temporary co-existence of polysemous and synonymous terms played a part in the creation of a specialized lexicon in the field.

$* * *$

\section{La polysémie : contributions à l'étude et au traitement grammatical, lexicogénique et lexicographique du phénomène}

La polysémie est l'un des problèmes principaux de la sémantique, où elle est parfois traitée sous le nom d'ambiguïté. La question paraît pourtant simple : tout le monde sait qu'un mot peut avoir plusieurs sens. Mais cette simplicité est trompeuse. Les lexicographes savent à quel point il est difficile de dire combien un mot a de sens, quels sont ces sens, où s'arrête un sens et où commence un autre. En fait, on ne pourrait répondre à ces questions que si l'on s'entendait sur ce qu'est le « sens » et ce qu'est un « sens »-ce qui est loin d'être le cas.

La sémantique lexicale moderne s'intéresse beaucoup à la polysémie. Elle a cessé de la voir comme une anomalie, et la considère désormais comme un trait fondamental de toute langue, indispensable à son fonctionnement. En outre, la polysémie a acquis une importance supplémentaire dans le cadre du TALN : elle constitue en effet l'une des clés à la compréhension automatique du langage. Parmi les principaux auteurs de travaux récents, on trouve - entre autres - des spécialistes de sémantique cognitive, des linguistes de corpus et des lexicographes. Ils aboutissent à des conclusions sur lesquelles tout le monde semble s'entendre :

- l'ambiguïté n'existe pas, ou guère, en discours, pour l'humain, qui peut presque toujours désambiguïser le contenu informatif en fonction des éléments du contexte, mais elle existe pour la machine ;

- il n'existe aucun moyen simple d'identifier les différents sens d'un mot ;

- la différence entre homonymie et polysémie, plutôt qu'une simple dichotomie, est à placer sur un continuum.

Certains linguistes et lexicographes de corpus finissent même par se demander si les sens existent, conclusion dangereuse qui remet en cause toute lexicographie et risque de décourager toute tentative de pousser plus loin les recherches. La question de l'ambiguïé demeure donc, même si elle a été déplacée. 
Les travaux des sémanticiens ont surtout porté sur les substantifs, parce qu'ils puisent dans les travaux des philosophes du langage, plus intéressés par l'exploration de la nature des choses que par le sens des mots, et aussi parce que c'est dans l'étude des substantifs qu'on se trouve le plus directement confronté aux problèmes liés à la référence. Depuis quelques décennies, il existe également des travaux sur d'autres parties du discours : le verbe, l'adjectif, certaines prépositions. Les problématiques récurrentes dans ce volume s'inscrivent toutes dans une tradition de sémantique lexicale et grammaticale aujourd'hui centrée sur la cognition.

La polysémie est devenue un immense champ de recherche, dont les travaux rassemblés ici ne représentent qu'une toute petite partie. Puckica étudie la polysémie des signes grammaticaux dans le cadre des grammaires de construction (GC), où les différents sens d'un signe linguistique peuvent être conçus soit comme des réalisations d'un sens abstrait « invariant», soit comme, dans la sémantique du prototype, des occurrences centrales ou périphériques d'une catégorie. Gilquin compare le réseau lexical de Norvig \& Lakoff [1987] pour le verbe anglais take avec des données issues de corpus et d'une expérience de production de phrases, du point de vue linguistique (le modèle reflète-t-il la fréquence telle qu'elle est attestée dans la langue ?) et cognitif (le modèle reflète-t-il la saillance dans l'esprit du locuteur ordinaire ?). Elle montre que le modèle ne tient pas face à l'analyse empirique, mais qu'il peut cependant avoir un rôle à jouer dans une théorie de la polysémie. Lorenzetti montre, à partir de l'examen des attestations du verbe anglais see dans un corpus, que dans la majorité de leurs emplois les verbes conservent des traits de leur sens prototypique, qui sert de support à d'autres extensions sémantiques. Stammers compare le traitement de la polysémie des adjectifs unbalanced, idle, canonical et particular dans six dictionnaires anglais récents. Les adjectifs constituent une classe très hétéroclite, et leur polysémie est fortement dépendante des contextes. Il observe que les traitements lexicographiques sont différents, et conclut que certains adjectifs traités comme polysémiques dans les dictionnaires ne le sont pas vraiment. Il remarque aussi que certains ont une polysémie clairement organisée alors que d'autres ont une articulation des sens qui résiste à l'analyse. Dury aborde la polysémie sous un angle peu usité : celui de son rôle en diachronie dans la formation d'une terminologie spécialisée, plus particulièrement dans le domaine du pétrole. L'examen d'un corpus de textes publiés entre 1800 et 1950 met en évidence des polysémies et des synonymies provisoires qui semblent servir d'étapes intermédiaires sur la voie de la mise au point de la terminologie du domaine.

Catherine Paulin Henri Béjoint 